Nikolay TSYREMPILOV

\title{
The Constitutional Theocracy of Lubsan- Samdan Tsydenov: An Attempt to Establish a Buddhist State in Transbaikalia (1918-22)
}

Translation by Jonathan Sutton

DOI: $10.22394 / 2311-3448-2016-3-2-26-52$

Nikolay Tsyrempilov - Buryat State University (Ulan-Ude, Russia). tsyrempilov@gmail.com

The paper examines the causes and circumstances of the establishment of a Buddhist theocratic state by Lubsan-Samdan Tsydenov, an outstanding figure of Buriat Buddhism. Drawing upon some hitherto unedited Tibetan, Mongolian and Russian sources, the paper undertakes a detailed reconstruction of the events in Siberian Transbaikalia in the period of the Russian Civil War. An analysis of personal notes by Tsydenov and the text of the constitution of the Kudun Buddhist state shows that "Kudun theocracy" was a syncretic fusion of the traditional Buddhist understanding of the Buddhist "Dharmic state" and modernist conceptions of republicanism and constitutional democracy. The Kudun theocracy should also be interpreted as a response of Buddhist circles to attempts by Buriat secular nationalists to build Buriat statehood based upon the idea of national self-determination. The Kudun project shows that Buddhism could serve as a foundation for state-building at the time of the early twentieth-century Russian political crisis.

Keywords: Buddhism, theocracy, Russia, Civil War, Buryatia, Lubsan-Samdan Tsydenov, constitution, modernity.

Work on the present article was carried out with financial support from the Ministry of Education and Science of the Russian Federation, within the core framework for academic activity (Project No. 3797: "Archaeographic and IT Methods in Research into Private Archives of the Baikal Region: The Creation of a Digital Store of Historical Sources"). 


\section{Introduction}

T $\mathrm{N}$ the second half of the seventeenth century, when the first Buddhist lamas from Tibet and Mongolia had already begun expounding their faith among Buriat tribes, Transbaikalia was incorporated into the Russian state according to terms of the Treaty of Nerchinsk (1689). The Buriats of Transbaikalia accepted subjection to Russian rule relatively peacefully, and this can largely be explained by promises regarding religious freedom that Fiodor Golovin, representative of the imperial crown, made to the Buddhists of Buryatia (Podgorbunskii 1901, 167). This promise was adhered to, but in general the history of the Buriat Buddhist community within the Russian state cannot be called simple. Unsuccessful attempts by imperial administrators to remove Buddhism from the territory of Russia, undertaken in the eighteenth century, which almost led to a mass exodus of Buriats from Russia to Mongolia (Natsagdorzh 2015, 18-39), were superseded by Catherine II's policy of religious toleration and a utilitarian approach. Alexander I and Nicholas I, having become reconciled to the presence of Buddhism within their borders, adopted a number of consistent measures with the aim of controlling the numbers and the extent of the spread of the Buddhist clergy (Gerasimova 1957; Tsyrempilov 2015). Even during the reign of Catherine II the affairs of the Buriat Buddhists had been entrusted to an administrative body created for this purpose, headed by a Bandido Khambo Lama (Chimitdorzhin 2010). The Buddhist community's religious leaders achieved a position of authority over the rank-and-file Buddhist clergy and a network of monasteries. During the second half of the nineteenth century, mutual relations between Buddhist lamas and civil administrators gained a degree of stability, but there were years during which they were overshadowed by short-term conflicts (Tsyrempilov 2007, 174-76, 196-99).

Right up to the beginning of the twentieth century, the system of self-rule by Buriats within the Russian Empire functioned on tribal lines. All Buriats were assigned to one or another Steppe duma, which served as the main bodies for tribal self-rule and were subject to the guberniia administration (Dameshek 1986, 40-41). The horizontal links between "dumas" were weak, which impeded the emergence, among Buriats, of a single ethnic awareness. Meanwhile, the network of Buddhist monasteries, headed by the Bandido Khambo Lama's chancellery, was the only system that drew a large proportion of the Buriat ethnosphere into a certain kind of unity. This probably accounts for the fact that, in terms of influence and authority, not a sin- 
gle member of the Buriat tribal elite could compete with the Khambo Lamas, who represented all Buddhists of the region, whereas the tribal heads represented only members of their own tribal community. With its centralized system of rule and its clearly defined center, Buddhism constituted a serious alternative to tribal self-rule, and the common interests of the Buriats as a whole were realized more effectively within the parameters of this system.

At the beginning of the twentieth century a third force was to shape and emerge on the scene, in the form of a Buriat secular intelligentsia, whose representatives had received their education at European universities and became the bearers of modernist ideas regarding nationalism, autonomy and national self-determination. Their thinking was already distinguished by general ethnic rather than tribal categories, and a large proportion of this secular intelligentsia regarded Buddhism as being "a point of refuge for a national spirit, national individuality and solidarity" (Rupen 1964, 1:34). They also viewed it as a force capable of consolidating the dispersed Buriat tribes.

The February and October Revolutions of 1917 and the Civil War offered Buriat nationalists an opportunity to realize their ideas in practice. In their attempts to do that, Buriat advocates of autonomy ("autonomists") tried to enlist the support of the Buddhist clergy. However, Buriat Buddhist leaders responded cautiously and mistrustfully to the pan-ethnic or nationalist strivings of their kinsmen. The Bandido Khambo Lama Guro-Darma Tsyrempilov and Agvan Dorzhiev offered direct support to the forces of restoration. In the course of negotiations with Alexander Kolchak, they promised him that they would carry out "propaganda against revolution and socialism" (Rupen 1964, 135). A proportion of the Buddhist clergy directly opposed the revolutionary movement and activists of the national movement, while paradoxically borrowing some very progressive ideas from their arsenal.

The project of establishing a Kudun theocratic republic occupies a special place in this history. It was initiated by Lubsan-Samdan Tsydenov, one of the most illustrious representatives of the Buriat Buddhist clergy. Tsydenov's state-building project is particularly interesting, inasmuch as it combines ideas of a Dharmic state headed by an enlightened Tantric deity with modernist principles of state organization of a republican character.

In the present article I shall attempt to explain the reasons why an ordinary Buriat lama arrived at the idea of a Buddhist theocratic republic; to trace the progression of his ideas; and to establish the sequence of events that led to the emergence of this state-building project. My 
interpretations will be based on a range of hitherto little-known sources, among which a typewritten manuscript by Ts. M. Ochirzhapov, a member of staff of the Anti-Religious Museum of the town of Verkhneudinsk (now Ulan-Ude), occupies a special place. This document bears the title, "The Theocratic Balagat Movement and Banditism in the Khori Aimak, 1917-1927." In this substantial account (92 typewritten pages), the author meticulously describes the course of events that took place in the Khori aimak of Transbaikalia during the specified period. In spite of the author's sharply biased evaluation of the activity of Lubsan-Samdan Tsydenov and his associates, the chronology of events set out by the author, as well as a mass of important details, strike me as being credible. A fortunate circumstance led to my obtaining a manuscript of Lubsan-Samdan Tsydenov's draft for a state constitution, written in Mongolian, ${ }^{2}$ which sheds light on what kind of political structure its founders had in mind. For the present article I have also used Tsydenov's own notes, written during several spells of imprisonment in Verkhneudinsk in 1921. These notes, written in Tibetan, Mongolian and Russian, include different kinds of observations on state structures in different parts of the world, quotations from Buddhist sutras, and complaints and petitions to judicial bodies. ${ }^{3}$ I have also used materials relating to the earlier years of his life, such as the Tibetan text of a poem that he wrote, describing the triumphant celebrations surrounding the coronation of Tsar Nicholas II, which took place in 1896. Tsydenov himself participated in the coronation in his dual capacity as a member of the Buriat delegation and as head of the Kudun monastery (datsan). ${ }^{4}$ I would like to express particular gratitude to my colleagues Gonchog Nyamochir, member of staff of the

1. This manuscript is preserved in the personal archive of the present author. Further, see Ochirzhapov. Aimak is a term that refers to one of the territorial units that were introduced under the Buriat-Mongol autonomy, and can also mean a military unit similar to a division.

2. The manuscript fills four pages of gray paper of Russian manufacture, measuring $23 \mathrm{x}$ $37 \mathrm{~cm}$. The title is: Urida qori-yin ayaimay-un buriyad qosiyun-ud-un medel-ün bayijsan-a tegüben oyoruyad edüge . . . Henceforth referred to as "the Constitution."

3. The L.-S. Tsydenov Archive. The Tibetan Holdings of the Center for Oriental Manuscripts and Xylographs of the Institute of Mongolian, Buddhist and Tibetan Studies.

4. The National Museum of the Republic of Buryatia. Temporary Holding. Inv. No. 422. The manuscript would appear to be a later copy of an original. The text is written in a school exercise-book, which has twenty pages of squared paper. In its Tibetan version it has the following extensive title: "New Song Inspired by the Great Joy of the Eventual Ascent to the Indestructible Diamond Throne of the Mighty Cakravartin, the Deity Established by Heaven, Tsar Nicholas, Praising the Enthronement, Narrating Briefly the Glory of Russia which Acquired the Might of Two Capital Cities, called 
Bogdo-Gegen Museum in Ulan-Bator, and Tsyren-Khanda Vladimirovna Ochirova, who, from 2005 to 2007 , served as director of the M. N. Khangalov Museum of the History of Buryatia. They, together with Dorzho Dugarov, helped me in searching for important sources.

\section{On the Eve of the Civil War}

\section{The Advocates of Autonomy and the Anti-Aimak Faction}

In Transbaikalia the February Revolution of 1917 set in motion a process of self-organization among Buriats and a movement for autonomy. In April of that year of revolution the First All-Buriat Congress was convened, and it established the Buriat National Committee (Burnatskom), which defined the task of reorganizing buluk and volost' administrations ${ }^{5}$ and replacing them with new territorial administrative structures on the model of, and similar to, those military-administrative units that had been introduced by the Manchus in Mongolia as far back as the seventeenth century. These were called somons, khoshuns and aimaks, denoting more or less metaphorically "arrows," "banners" and "divisions" respectively. It was the Buriat bourgeois nationalists, as they were referred to in Soviet historiography, who became the principal driving force of the movement for Buriat autonomization. Their most well-known representatives were the Social Democrat Elbeg-Dorzhi Rinchino (1888-1938), the social activist Mikhail Bogdanov (1878-1919), the renowned scholars Bazar Baradin (1878-1937), Tsyben Zhamtsarano (1881-1942) and Dashi Sampilon (1891-1938), the Buddhist lama and diplomat Agvan Dorzhiev (1856-1938) and others (Rupen 1964, 29). One could not call this a unified group, but overall its members agreed on the necessity of ensuring their own administrative and cultural autonomy within the new Russia. Advocates of the restoration of the Statute of 1822 drawn up by Mikhail Speransky ${ }^{6}$ made up a separate group, initially called the "Old Duma" faction

'Repeatedly Gazing at the Terrifying Bengal and African Lions in the Zoological Garden'” Henceforth: "New Song."

5. Buluk and volost' - the basic administrative units used by the Buriat population of Transbaikalia, introduced due to the volost' reform at the beginning of the twentieth century.

6. The statute "On the Administration of Non-Russians," elaborated by M. M. Speransky when he served as general-governor of Siberia in 1822, set out a system of administration for the non-Slavic peoples of Siberia, including the Buriats, based on principles of self-rule. 
(starodumtsy), which included former officials of the steppe dumas ${ }^{7}$ and part of the Buddhist clergy, who considered the system of Buriat self-rule, which had been abolished at the turn of the century, as answering the principal needs and hopes of the Buriats. Erdeni Vambotsyrenov, former taisha of Khori Steppe Duma, ${ }^{8}$ was leader of this particular group (Istoriia Buriatii, 13). A section of the Buriat Buddhist clergy joined this group, also speaking out firmly against any changes whatsoever in the Buriats' long-lasting system of secular and religious self-rule.

\section{Creating the Structures for Buriat Autonomy}

The question of restoring the steppe dumas was raised by the Old Duma faction during proceedings of the First All-Buriat Congress, convened in Chita in the first months after the February 1917 revolution. At that time E.-D. Rinchino managed to persuade the Old Duma faction not to include this matter in the Congress's resolution. Instead, the Congress resolved to recommend the creation of an autonomous territory for the Buriats, divided up into three types of territorial unit, structured hierarchically in the following order: aimak, khoshun and somon. The Buriat National Committee became the superior regulatory structure of the autonomous region. The Buriat National Committee arranged for the Khori aimak to comprise eleven khoshuns according to the number of tribes that were to be included in the sub-ethnic grouping of "Khori Buriat-Mongols."

In the course of discussing the Congress's resolution, a small group of Old Duma faction deputies, headed by Genin Tsyrempilov, head of the Kudun (Kizhinga) datsan, and by Burnobadara Dalayev, a former Khornisk zaisan, ${ }^{10}$ expressed public dissatisfaction regarding the use of military terminology to name territorial units of the Buriat autonomous region. This military terminology seemed to them to be menac-

7. Steppe Dumas - organs or instruments of self-rule for the native peoples of Siberia, employed from 1822 until end of the nineteenth century and beginning of the twentieth century.

8. Taisha - a Chinese-derived term for a Buriat tribal chief (Rupen 1964, 23). Before the abolition of steppe dumas, Erdeni Vambotsyrenov had been the chief taisha in the Khori Steppe Duma.

9. Khori Buriats, Khori Buriat-Mongols: the self-appellation of one of the largest sub-ethnic groups that make up the Buriat people. They live in Central and Eastern Transbaikalia.

10. Zaisan: A post in the hierarchy of ranks of the steppe duma administration. 
ing in itself and also seemed to anticipate an impending militarization of the Buriat-Mongols (Ochirzhapov, 2). Obviously claims regarding the naming of territorial units were only an external manifestation of Old Duma dissatisfaction with the Buriat National Committee's (Burnatskom's) reversal in favor of autonomization. After that, participants in the Congress paid no more attention to the dissatisfaction of its faction from Kizhinga. Many prominent representatives of the Old Duma faction received jobs in the administrations of aimaks, khoshuns and somons, and Erdeni Vambotsyrenov, the leader of the conservative Old Duma faction, became part of the Khori aimak's Committee for Social Security. It seemed that a compromise among the different groups of Buriat activists had been found.

However, soon the rivalry between the autonomists and the Old Duma faction resulted in a serious confrontation. On June 17, 1917, the Provisional Government adopted a resolution on the introduction of local government (zemstvo) administration in Siberia. This signified the demise of the Old Duma faction's hopes. The Old Duma faction assumed that now the Buriat Mongols would again be defenseless before the power of the Russian majority. The autonomists were declared to be at fault for this failure, in particular E.-D. Rinchino, who, during the work of the First Congress, had persuaded deputies not to put forward a petition regarding the restoration of the steppe dumas. Tension increased yet further when, as a result of elections organized in Transbaikalia on January 18, 1918, representatives of the autonomists made up almost all the voters at the zemstvo level. At the elections the Old Duma faction was unable to consolidate sufficiently early and put forward its own candidates, all the more so since voting was conducted according to lists drawn up in advance. Among the conservatively inclined Buriats there was talk of the dominance of representatives of the Buriat national intelligentsia within the structures of power (Ochirzhapov, 3).

The Movement against Military Conscription, and Consolidation of the Anti-Aimak Faction

Ataman Grigory Semyonov's accession to power signified a new wave of opposition to the Anti-Aimak faction on the part of the autonomists. In October 1918, the Buriat National Committee, now transformed into the Buriat National Duma, headed by Dashi Sampilon, addressed itself to Ataman Semyonov with a petition regarding an institution of Buriat autonomy (Istoriia Buriatii, 3:35). However, for Semyonov himself the priority task was to summon young Buriats into the ranks of his 
own armed forces, which were called Tsagan Tsagda, or the "White Guard" (Bartanova 1964, 36-37). For representatives of the Buriat National Duma the question regarding autonomy basically came to depend on the success of the campaign of military conscription. The followers of Semyonov attempted to convince the Buriats that recruitment to the Tsagan Tsagda was not a military call-up as such, inasmuch as (a) Buriats were being called to serve for fewer than six months, which was a significantly shorter time period than for the rest of the population; and (b) Buriat conscripts would perform their military service strictly within the confines of Buriat territory and exclusively with a view to maintaining internal order. However, these arguments did not carry any weight with the majority of Buriats, and they categorically rejected the requirement of military conscription (Ochirzhapov, 8). However, Semyonov had no intention of relinquishing his idea of enlisting them to serve in the ranks of the Tsagan Tsagda. In Buriat circles the mood that had arisen against a military call-up was intensified yet further when, in January 1919, a rumor went around the Buriat aimaks that LubsanSamdan Tsydenov, the famous Buddhist lama and recluse from Kizhinga, intended to create a theocratic government with the goal of defending Buriat Buddhists from the violence of the Civil War.

\section{A Holy Fool}

\section{A Promising Beginning}

Lubsan-Samdan Tsydenov was born in 1850 in the settlement of Kizhinga in the territory of Khorinsk. While still only a child he was placed in Kizhinga (Kudun) Monastery where, after some time, he began studying philosophy, which he continued when he lived at the Tamcha datsan, the residency of the Bandido Khambo Lamas. From early childhood he displayed an inclination toward studying, thanks to which he received the monastic qualification of gabzhi. ${ }^{11}$ One source informs us that Tsydenov was particularly committed to the practice of meditation. ${ }^{12}$ His contemporaries described him as being reserved and disposed toward solitude, having limited contact with people around him, and as abstemious in his daily living. However, his rare person-

11. Gabzhi (Tibetan, dka bzhi): In Tibetan and Mongolian Buddhism this is one of the higher scholarly degrees conferred on monks.

12. The biography of Lubsan-Samdan Tsydenov is based on information set out by Ts. M. Ochirzhapov on pages $80-87$ of his manuscript. For a detailed biographical sketch, see Tsyrempilov 2007, 45-52. 
al charisma and exceptional level of scholarship raised his authority among believers, and this allowed him to take part in elections for the position of the head of Kudun Monastery. Other sources inform us that he is supposed to have had dreams regarding his own appointment as head of Kudun Monastery and that, allegedly, he even had pretensions to the throne of the Bandido Khambo Lamas, the highest administrative position among the Buddhist clergy of Eastern Siberia. Nevertheless, in a competitive contest for this position, Tsydenov lost to another claimant, who enjoyed the support of Choinzon Iroltuyev, active as a Khambo Lama at that time. By way of moral compensation for that defeat, Iroltuyev included Tsydenov in the Buriat delegation to the 1896 coronation of Tsar Nicholas II. If we are to believe this information, authoritative representatives of Buryatia's tribal aristocracy contributed to Tsydenov's inclusion in the delegation (Zhigmidon, 2).

\section{A Scandal at the Coronation}

In March 1896 the delegation set off for Krasnoyarsk, where they switched from post-horses to railway to complete their journey to Moscow. ${ }^{13}$ Secular and religious representatives of the Buriats of Transbaikalia took part in the ceremony of Nicholas II's coronation in the Uspensky Cathedral within Moscow's Kremlin and in the subsequent lavish celebrations in Moscow and St. Petersburg. During the grand ceremony of the coronation Tsydenov refused to kneel, which not only put the entire Buriat delegation in an awkward position, but also led to an investigation of the incident by the Ministry of Internal Affairs. Tsydenov himself explained his action thus: that as a full monk, he enjoyed the privilege of not being obliged to bow before the tsar, and that "no criminal action was committed by [his] not taking part in bowing." Furthermore, "the fact that members of the Buddhist delegation did bow represented a departure from the standards of Vinaya ${ }^{14}$ discipline and was shameful, particularly on the part of Khambo Lama Iroltuyev, as a gylun (a Buddhist monk who has taken full vows $)^{15}$ and as leader of the Buddhist clergy of Siberia" (Ochirzhapov, 81). All this notwithstanding, on August 20, 1896, Samdan Tsydenov,

13. In the personal (archival) holding of L.-S. Tsydenov there is an attestation (No.151) confirming that he was designated to travel to and attend "the holy coronation of their imperial majesties" (Center for Oriental Manuscripts and Xylographs of the Institute of Mongolian, Buddhist and Tibetan Studies, File 636, p. 5).

14. Vinaya: The canonical code of discipline to which Buddhist monks adhere.

15. Gelon: (Tibetan dge slong) or bhikșu, a Buddhist monk who has taken full vows. 
like the other members of the delegation, was awarded a silver medal on an Andreyev ribbon. ${ }^{16}$

\section{An Enthusiastic Monarchist?}

We see even more singular and important evidence of what kind of influence the encounter with Europe exerted upon Lubsan-Samdan Tsydenov in a lengthy poem dedicated to the coronation of Nicholas II that he composed in Tibetan and Mongolian.

We can assume that Samdan Tsydenov really felt that he could refuse compliance with the coronation ceremony, citing the quite reasonable arguments elaborated in the sketch already mentioned. This is all the more likely if we take into account the Kudun hermit's wellknown integrity and originality. Nevertheless, there are three places in the pages of his poem where Tsydenov pays respect to the person of the monarch, thereby declaring his own relation to the emperor as to a sacral figure. Samdan Tsydenov was not prepared to venerate the emperor ceremonially in a concrete situation, but internally, and as a bearer of power, the emperor fully merited being seen as an object of his veneration. One way or another, it seems entirely natural to suppose that the person who composed such a significant and triumphal work about the splendor, greatness and sanctity of monarchical power, even if only partially relating to Buddhist civilization, esteemed monarchy as sacred. News about the shooting of the tsar's family was circulated by Russian newspapers in summer 1918, and one can guess what kind of impression this would make on a person who had regarded the emperor as a divine figure. In his eyes could any other power be accepted as legitimate, whether it be the Provisional Government, the Soviets, the structures of Buriat autonomy or Ataman Semyonov? The monarchy that had been done away with could be replaced only by another monarchy possessing the explicit attributes of sacrality the power of an enlightened deity.

In all probability this idea came to Tsydenov in autumn 1918 when the conflict between representatives of the Buriat National Duma and the Anti-Aimak Faction regarding military conscription reached an acute phase. The opponents of conscription and autonomization lacked a single leader and an alternative idea that could counter the

16. The personal archival holding of L.-S. Tsydenov contains the official testimony that he was granted this award (Center for Oriental Manuscripts and Xylographs of the Institute of Mongolian, Buddhist and Tibetan Studies File 636, 5). 
movement for the autonomy of Buryatia. Among believing Buddhists the idea of a Buddhist theocracy was already highly popular, as they already had the living examples of the Dalai Lama and the Jebtsun Damba Khutukhtu at the summit of the theocracies of Tibet and Mongolia respectively. Either personally or through those close to him, Lubsan-Samdan Tsydenov would transmit this idea to authoritative members of Kizhinga's Anti-Aimak Faction, who were beginning to act.

\section{How the Kudun Theocracy Was Structured}

\section{Invitation to the Throne}

In the conditions of administrative chaos that reigned throughout Russia during the Civil War, credit cooperatives and consumer societies were often the only structures fulfilling any organizational functions. In Kizhinga the credit association in fact became the platform on which Lubsan-Samdan Tsydenov created his constitutional theocracy project. In January 1919 members of the administration of Kizhinga's credit association were summoned to an extraordinary closed session. At this session it was not financial matters that came up for consideration, but a question of political importance: the secession of Kizhinga from the Khori aimak and the creation, on territory of the former Bodongut somon, of a state organized on theocratic principles (Ochirzhapov, 9). The initiators of this scheme were local inhabitants S. Genintsybenov, G. Garmayev, D. Iroltuyev and S. Gonchikdarayev, all of whom were to receive prominent positions in the future theocratic government. Activists proposed that members of the credit association create a ceremony for transferring a mandala ${ }^{17}$ to Lubsan-Samdan Tsydenov, with a request that he ascend the throne as the religious head of state and thus ensure that local Buriat Buddhists were protected from military conscription and, in general, from the politics of the Buriat National Committee. In line with a decision of the gathering, a campaign began among the Buriats of Kizhinga in support of a collective written petition, and a collection was organized so as to raise contributions for a future ruler.

17. Mandala (Sanskrit: mandala, lit. circle, disc). In Hinduism and Buddhism this is a symbolic depiction of the universe, showing as a disc with a raised pyramid-shaped or coneshaped center. In the Buddhist tradition the mandala is one type of offering brought to a teacher or to a spiritual person of any kind. 


\section{Structure of the State}

Tsydenov gave the initiative group instructions regarding the drawing up of a constitution for the established state; its basic institutions had to be formed and a constituent assembly had to be convened. The constitutional commission that was created comprised twenty-two individuals, taken mainly from among highly placed lamas of the Kudun datsan and civil servants within the volost' or somon administration (Ochirzhapov, 11). On May 4, 1919, a draft version of the Constitution of the Theocratic Government of Kudun Valley was completed, consisting of thirty-six articles. The draft specified the structure of the state's secular administrative bodies, and officially assigned it the title Erkhete Balgasan Ulus', which can be translated as "Sovereign State of the Balagats." The founders of the state understood the term balagat as signifying the largest administrative and territorial unit, which included toskhons that themselves approximately corresponded to what had been the somons. Balagats also corresponded to khoshuns. In the new government the territorial entities that had corresponded to aimaks simply did not exist (Ochirzhapov, 12-13).

According to its fundamental law, ${ }^{18}$ the Kudun state was under the supreme rule of Lubsan-Samdan Tsydenov, known by his titles of Yogachari Nomun Khan and Tsog Tuguldur Darmaranza. ${ }^{19}$ He ruled the state according to the rights of a person who had realized within himself the Tantric divinity Yamantaka and was performing the will of that deity. Next in the Kudun theocracy's hierarchy of power there was a representative assembly - the Great Suglan (yeke čijulyan). ${ }^{20}$ Deputies were elected to the Suglan by means of a direct secret vote in the ratio of one deputy per hundred voters. Males and females over the age of fifteen years were entitled to vote. And, in their turn, deputies in the Suglan voted for members of the Presidium. The state budget and the responsibility for defining salary scales were under the Suglan's jurisdiction.

18. Here and henceforth analysis of the fundamental law of the state of Erkhete Balgasan Ulus is based on the Mongol language version of the constitution (pp. 1-4), preserved in the personal archive of the present author.

19. The given appellation is a combination of Sanskrit and Mongol words which, in their literal sense, mean: "Yogi, King of the Teaching, Majestic and Absolute Ruler of the Dharma." Darmaranza is a Mongol translation of the Sanskrit term dharmarāja , used in Hindu and Buddhist traditions to denote a ruler who protects religions.

20. Here and henceforth the original Mongolian terminology is given in parentheses, in the very form in which it is provided in the above-named source. 
Directly subordinate to the Darmaranza are the president, the vicepresident and the cabinet of ministers. All elected officials had to be confirmed by the Darmaranza. Likewise, important government decisions had to be approved or confirmed by the Darmaranza. However, decisions relating to current issues in operational management were made independently by the president. Correspondingly, government orders needed to have the president's approval.

The theocracy comprised eleven balagats or administrative-territorial units. Their administrations (balayad-un jakiruy-a) came under the direction of the heads of administration (balayad-un ejen) and their assistants. Also, officials at the balagat level were themselves elected by residents in the balagat for a two-year term. The toskhons, the smaller units that made up the balagats, were regulated by dargas $($ daru $-a)$, who were voted in to serve for one year. Balagat assemblies, at which the heads of balagat administrations were elected, required two-thirds of the voters to be present in order to proceed. Likewise, it was the voters themselves who determined the officials' salary levels.

The third branch of government was the balagat court, which was presided over by the balagat's head of administration and two elected judges (siülengge). For the preservation of internal order the position of supervisor (čaydayači) was introduced, together with his assistants, and the balagat guards (amuүulang-i kinayčid) were subject to them.

Lubsan-Samdan Tsydenov, now named as the theocracy's leader and as Lama Darmaranza, simultaneously affirmed the constitution and summoned a Great Suglan to be convened on May 14, 1919 (the first year according to the chronology of the balagat state), in Shalsan in the valley of the Kudun River (Ochirzhapov, 12-13). On the appointed date, 102 deputies were chosen and brought together, and they approved a working version of the constitution, declared the creation of a new state and made the decision to bring a mandala before LubsanSamdan Tsydenov, asking him to lead. Besides this, his closest follower Dorzhi Badmayev was officially appointed as heir to "Tsar-Despot"11 Tsydenov. After the end of the first session of the Great Suglan, its members as a whole went to the place known as Khaltsagai Tolgoi in order to hand Tsydenov a mandala and ask him to ascend the throne. Right then and there the officials elected by the Suglan swore an oath of allegiance and took up their new duties (Ochirzhapov, 16-17).

21. Lubsan-Samdan Tsydenov called himself "tsar-despot," apparently trying by this means to underline the autocratic nature of the government he created, despite the overall republican system of its administration. The status of the theocratic head of the Kudun state was located above that of the fundamental law and of the organs of power. 


\section{A Collision with Reality}

During the first days of May the government of the newly created state gathered together for its first session of business. That very same day saw the arrival, in the Khori aimak, of Colonel Korvin-Piotrovsky, who was in charge of Verkhneudinsk District and, on this occasion, was under orders from Grigory Semyonov. At the same time a Cossack officer called Rabdanov was sent from Chita, together with an armed detachment. Both of these trusted subordinates had orders from Semyonov to investigate what was actually going on in the aimak and, if necessary, to arrest the initiators of this separatist movement (Ochirzhapov, 19). Given that Lubsan-Samdan Tsydenov's theocratic government was organized on non-violent principles, and therefore its government lacked a military authority, it was, in real terms, defenseless in the face of any armed forces. The sole means of self-defense for the subjects of the balagat state were appeals and proclamations. Thus, having found out about the approach of Semyonov's troops, members of the government of the theocratic state sent dispatches, one after the other, to the Buriat National Duma in Chita and to Ataman Grigory Semyonov personally, with requests to leave the newly created theocracy in peace (Ochirzhapov, 19). At that time the conviction spread among the population that, thanks to the miraculous strength of the Darmaranza, all his opponents would, naturally, be disgraced and rendered harmless, their weaponry would be turned into trinkets and Tsydenov's residence would be surrounded by miraculously arising fortifications (Ochirzhapov, 19). Meanwhile Colonel Korvin-Piotrovsky's and Rabdanov's detachments were joining forces and heading straight toward the boundary of Khaltsagai-Tolgoi, the name of which had by that time been changed to Soyempkus. Also, officials of the aimak administration were arriving, including Dul Tsydenov, a member of the aimak Duma, and Erdeni Vambotsyrenov, head of a district of the Khori aimak (Ochirzhapov, 12-13). The latter of these found himself in a very awkward situation inasmuch as he was an ally and follower of Lubsan-Samdan Tsydenov, but in this case he also represented the aimak administration, which was recognized by Semyonov.

After twice being issued with an ultimatum requiring him to give himself up to the authorities voluntarily, Lubsan-Samdan Tsydenov was obliged to submit. He and a number of members of his government were placed under arrest. Some ministers and other highly placed administrators succeeded in hiding in remote settlements and wooded locations. In connection with this, members of their families 
were also subjected to arrest and interrogation, during which Semyonov's troops permitted the use of violence and corporal punishment. Officer Rabdanov even dared to punish Lama Galsanov of the Kizhinga datsan with birch rods for his complicity in the flight of Genin Tsyrempilov, head of the datsan. Subsequently, owing to this episode, Korvin-Piotrovsky was obliged to dismiss some of Rabdanov's subordinates from their duties (Ochirzhapov, 23).

A search of Tsydenov's prison cell was carried out, with the aim of finding documents or objects relating to his case. As the sources inform us, in the course of this search, among other things found in his cell were a crown with a vajra [a ritual tool or weapon-Ed.] and a human skull depicted on it, diaries containing a list of people who had made donations, some Buddhist religious literature, a collection of books and journals in European languages, and also a belt mounted with electric lights, which Tsydenov is supposed to have acquired in Petersburg and which he allegedly used for creating an impression on his believers. ${ }^{22}$

Some days later Lubsan-Samdan Tsydenov, his close associate Dorzhi Badmayev and a number of members of his government were transferred to Verkhneudinsk prison and interrogated. In particular, as our sources inform us, Tsydenov declared the following during the interrogation:

In connection with the overthrow of tsarism and the formation of a Provisional Government, in many places in Russia a number of new states have been set up, declaring their independent existence [. . .], which has created a rift and hostility among them, internecine strife, anarchy, the mobilization of troops and the declaration of war against each other, and so forth. This was conveyed to me by arriving Buriat supporters, complaining about the actions of the Buriat intelligentsia and their aspiration to call young Buriats to armed service in the tsagda [White Guard] so as to preserve the national autonomy that had been achieved through their initiative, and so forth. [. . . I In the given situation I was obliged to declare myself the tsar-despot of a theocratic state that pursues the goal of opposing military recruitment and war, and pursues peace based on specific rules provided for in religious doctrines. I did this, while setting my hopes on Buriat Buddhists avoiding that very autonomous structure

22. See "Description of Tsydenov's Arrest," Center for Oriental Manuscripts and Xylographs of the Institute of Mongol, Buddhist and Tibetan Studies, Mongolian Fond, Collection M1, 516, ll. 1ob.-2 and Ochirzhapov, 21. 
of administration that would entail their being called up for military service. I further hoped that they would stand behind my idea and that the government in question would be safeguarded by the supernatural power of a divine protector, and that these ideas would not be rejected by the surrounding Russian population, which has suffered as a result of war and internecine strife. However, despite all this, I consider my initiative to be a mistake, explained by my advanced age, my political ignorance, and my immersion in contemplation and isolation from society while the abovementioned events were taking place. ${ }^{23}$

This statement of Tsydenov's supported an official call to his subjects and to members of the government that he formed, asking them no longer to consider him as their ruler and to submit to the powers of government represented by Ataman Semyonov. This call brought to an end a movement to affirm allegiance to Tsydenov that had already begun among the population of other Buriat aimaks such as the Batanai-Khargana, Khuatsai, Chikoi, Selenginsk and Orongoi aimaks.

These explanations and Tsydenov's voluntary disavowal of power were sufficient for Semyonov. Obviously the authorities were afraid of a worsening of relations with the Buriat population, among whom Tsydenov's authority stood very high. The authorities very openly punished the police under Rabdanov for having permitted excesses, and they released all Tsydenov's supporters who had been detained, and also Tsydenov himself. As subsequent events were to show, Lubsan-Samdan Tsydenov's declarations repenting of his actions were no more than a tactical ploy. His return to Kizhinga was triumphant. He was welcomed by numerous believers, many of whom considered the very fact of his release to be evidence of his spiritual power. Upon returning to Soyempkus, Tsydenov declared that the events that had occurred were intrigues on the part of the Buriat autonomists, who were striving in this way to direct the resentment of his followers at members of the Buriat National Duma, not at the followers of Semyonov. By these means Tsydenov was probably attempting to show his subjects that Grigory Semyonov had no grounds to challenge him because Tsydenov's activity was within the bounds of legality. To many of Tsydenov's followers at that time it might have seemed that his arrest and interrogation were simply the fruit of a misunderstanding. That position would be likely to convince Semyonov himself for some time into the future that the Kudun theocracy had no harmful implications for his regime.

23. See "Description of Tsydenov's Arrest," ll. 10b.-2, and Ochirzhapov, 21. 


\section{Conflicts around the Question of Military Recruitment}

Meanwhile, the fundamental issue in mutual relations between the advocates of theocracy and Semyonov's ruling apparatus remained the question of the conscription of Buriats into the detachments of the Tsagan Tsagda (White Guard). The antiwar propaganda they energetically pursued on the ground, as well as the appeals to Semyonov's government demanding it to release Buriats from military service, obliged Semyonov to respond. On three occasions during the period from May to December 1919, Lubsan-Samdan Tsydenov and some of those close to him were subjected to arrest and incarcerated in prisons in Verkhneudinsk and Chita. However, each time they were detained for a relatively brief period (on average for about a month) (Ochirzhapov, 21-22). Among Tsydenov's believing followers the conviction strengthened that their spiritual leader was invulnerable to the repression of the authorities and that each time he emerged from imprisonment by miraculous means. After one of these arrests, D. Badmayev and S. Gynintsydenov, who had been close to him, died of typhoid, and in their honor stupas were erected next to Tsydenov's cell in Soyempkus. For several days Dorzhi Badmayev's body was venerated by believers, and then it was placed inside a stupa as if in a mausoleum. In connection with Badmayev's death, his three-year-old stepson Bid'ia Dandaron was declared to be Tsydenov's heir (Ochirzhapov, 29).

Meanwhile, the advocates of theocracy continued to resist the authorities' initiatives concerning the question of calling Buriats up for military service. This resistance occurred against the background of Semyonov's successful cooperation with other representatives of the Buddhist clergy of Buryatia and Mongolia, such as Bandido Khambo Lama Guro-Dharma Tsyrempilov, and also Neisse-Gegen and Toin-Khutukhta from Inner Mongolia (Ochirzhapov, 32). Thus, within the framework of a congress of representatives of the Buriats of Transbaikalia that convened in October 1919 on the initiative of the Buriat National Duma, at which the above-mentioned august, spiritual individuals were honored delegates, it was recommended that the Duma organize a military administration with the goal of setting up a military conscription of Buriats into a national Buriat force for "the restoration of its native land and for the establishment of order inside the country" (Bazarov and Zhabayeva 2008, 158-60). Advocates of the Kudun theocracy did not take part in the work of this congress and, furthermore, they declared to Semyonov that they had no intention of complying with anyone's orders about setting up military recruitment within 
their territory. Annoyed by Tsydenov's obstinacy, Semyonov again had him arrested for a short time (Ochirzhapov, 28). However, in March 1920 Semyonov's regime fell and Semyonov himself fled to Manchuria.

\section{Resistance to the New Authorities}

As is well known, the rapid advance of the Red Army into Transbaikalia did not lead to the immediate establishment of Soviet power there. In April 1920 the Khori aimak was on the territory of the Far Eastern Republic, which was a buffer state created by the Founding Congress of the Workers of the Baikal Region. At almost the very same time, within the Far Eastern Republic, a Buriat-Mongol Autonomous Region (BMAR) was established as a national and territorial entity. It worked out that the part of the Buriat population resident in the Barguzin, Verkhneudinsk, Selenginsk and Troitskosavsk districts were included in the composition of the Baikal Region, with Verkhneudinsk as its capital (Ochirzhapov, 28).

In order to lead the process of Sovietization in the Buriat aimaks of the Far Eastern Republic a Buriat popular revolutionary committee (Burnarrevkom) was created, headed by Pyotr Dambinov, a representative of Buriat intelligentsia (Bartanova 1964, 50-58). Taking advantage of the changeover of power, a number of prominent activists in the theocratic movement entered the composition of newly formed revolutionary committees at somon and khoshun levels. Moreover, those in the theocratic movement succeeded in establishing close alliances with highly placed officials in the Baikal Region, specifically with Alexei Uvarov, head of section of the Verkhneudinsk district police; with Karpovich, senior investigator of the Baikal Region's Political People's Court; and others. With their help the advocates of theocracy managed to strengthen their own positions at the local aimak level and even to conduct an armed struggle against their opponents, whom they accused of collaborating with the regime of Ataman Semyonov (Bartanova 1964, 67). In general, Tsydenov's supporters were active in attracting allies to their side. Thus, thanks to their own contacts, they were able to publish the brochure, "What Is the Theocratic Movement Fighting For?" through the Military Administration of the Baikal Region. In this brochure a certain Grigory Strefyev put forward the idea that the advocates of theocracy were precisely that oppressed minority whose freedom the new power had been called to guarantee. However, the brochure was confiscated almost immediately and its author was prosecuted (Ochirzhapov, 33). 
From the very beginning the administration of the Far Eastern Republic followed a course of strengthening the revolutionary committees at aimak level in the Buriat-Mongol Autonomous Region and combating separatism. As part of this course of action, the administration of the Far Eastern Republic ordered the arrest of Tsydenov, of Sandylyk Gonchikdarayev, president of the balagat state, and also a number of ministers of the theocratic government. Tsydenov was detained in Verkhneudinsk's prison, from which he never again returned to the $\mathrm{Ku}-$ dun Valley (Ochirzhapov, 36-37). The notes from prison that he wrote during that period of his life have been preserved (Ochirzhapov, 3233). Among other material, the notes contain many European terms taken from the field of political theory and state formation, which he had copied out from an encyclopedia that he had at his disposal.

In his notes the entry on "theocracy" occupies a significant place, with the term being defined in the following way: "Theocracy is a form of government in which God is considered to be the head of state, as it were conveying orders and prohibitions to the priests; the clergy rule the state, acting, as it were, according to the inspiration of the deity; a state having such a structure" (Archive of L.-S. Tsydenov).

Post factum Tsydenov was purposefully searching the literature for examples of hierocratic and theocratic forms of government in other countries of the world, and for a theoretical foundation for the form of power that he had chosen for his own project of state formation.

In addition to this, a fragment of a draft manuscript has been preserved, namely Tsydenov's appeal to the political court of the Baikal Region of the Far Eastern Republic. In it he provides his own (albeit rather official-sounding) explanation of his motives for creating a theocracy:

I really am the Ruler of the Teaching (Dharmarāja) of the Three Worlds. This power was sent down to me by the divinity. Inasfar as, for my followers, I have been regarded as a savior, in their encounters with me they have venerated me by bowing before me, conducting a service to promote [my] health and by bringing me gifts.

As we have a theocracy, so the majority of my supporters are adepts, and therefore they need to have particular attributes and signs and adhere to appropriate forms of behavior. They are linked together by a ban on killing and by further vows of purity. In accordance with these, it is impossible for them to serve in the army in any circumstances whatsoever. Inasfar as theocratic politics is linked with religion, it views politics and religion as being in close connection with each other. Thus, ac- 
tions associated with the "ruling lama" are viewed as religious, and it is impossible to consider any of the actions I have carried out as crimes (Archive of L.-S. Tsydenov, 1. 128).

\section{The Storm Clouds Gather}

Despite Samdan Tsydenov's prolonged confinement in prison, his supporters did not reduce their activity. With the support of Police Chief A. Uvarov and other officials in the administration of the neighboring Baikal Region, the leaders of the balagat movement called an assembly of the inhabitants of the Khalbin, Tsagan and Bodongut khoshuns, at which a decision was taken for these khoshuns to withdraw from the Buriat-Mongol Autonomous Region and, instead, to transfer into submission to the government of the Baikal Region. For this purpose they revived the entire administrative system of the balagat state, which, two years previously, had been set out in the constitution: the balagat and toskhon administrations, headed by a chief ${ }^{24}$ and an elder. ${ }^{25}$ The advocates of theocracy refused to pay taxes that benefited the Buriat-Mongol Autonomous Region and they organized their own police forces. The leadership of some somon and khoshun administrations of the Khori aimak voluntarily ceded matters to balagat leaders and across the whole aimak a process of persecuting autonomists got under way. In this connection, police attached to the Baikal Region, whose actions were coordinated by Karpov the investigator, gave active help to the theocratic movement in detaining the autonomists. The campaign against the autonomists was conducted under the guise of a struggle with the remnants of "Semyonov's lackeys." As a result of all this, many somon- and khoshun-level employees were forced to flee to neighboring aimaks or else hide in forests (Archive of L.-S. Tsydenov, 38-40).

In the summer of 1921, Lubsan-Samdan Tsydenov, then still detained in prison, asked the following long-standing advocates of theocracy-G. Tsyrempilov, N. Sampilov, Sh. Tsybikov, D. Dorzhiev, Ts. Bazarov and others-to organize a celebration in honor of the restoration of the balagat state in the newly opened datsan in Chuluta. The festivities, which lasted for two to three days, included prayers, horseracing and wrestling. Allies of the Kudun balagats Uvarov and Karpovich, two officials of the Baikal Region, were officially rewarded by

24. Ezen - translation from the Buriat word for "master" or "head."

25. Darga - translation from the Buriat word for "chief." 
representatives of the balagat movement with silk scarves and animal furs for the help they had given the Kudun theocracy. The focal point of the whole program of celebrations was the triumphant enthronement of Lubsan-Samdan Tsydenov's heir, the nine-year-old stepson of Dorzhi Badmayev, Bid'iadara (Bid'ia) Dandaron, who was later to become a renowned religious philosopher, Tibetan scholar and Buddhist dissident. ${ }^{26}$ A little while before that coronation, Dandaron had been recognized by Lubsan-Samdan Tsydenov as being a reincarnation of the Tibetan Lama Jayak-Gegen ${ }^{27}$ of the Gumbum Jampaling Monastery, ${ }^{28}$ who had more than once visited Kizhinga. Later in life Bid'ia Dandaron underwent repression and persecution over a period of many years on account of his status as a reincarnated being and because of his own involuntary and unsought association with the theocratic movement.

\section{Movement toward a Compromise}

Meanwhile, the situation in the Khori aimak became more acute due to an increase in skirmishes between young people supporting the theocracy movement and the pro-aimak faction (Ochirzhapov, 40). The intensification of anti-aimak feelings forced the government of the Far Eastern Republic to take action. In July 1921 a government commission was sent to the region, headed by D. S. Shilov, a member of the Far Eastern Republic's administration. After carrying out an investigation, the commission was categorical in its demand that participants in the balagat movement surrender their firearms and submit to the aimak and khoshun authorities. The commission also required that officials of the Baikal Region cease all interference in the affairs of one of the aimaks of the Buriat-Mongol Autonomous Region. Besides this, D. S.

26. B. D. Dandaron (1914-74), Buddhist religious activist, specialist in Buddhist philosophy, and religious philosopher. Was arrested in 1937 and in total spent about twenty years in Stalin's camps. After his release and rehabilitation in 1957 he worked in the Buriat Institute of Social Sciences. In the 1970 s he founded a religious community, which included a circle of educated young people from various parts of European Russia. In 1974 he was arrested and accused of setting up an illegal religious organization. He was sentenced to five years in ordinary regime camps. He died in captivity in the settlement of Vydrino in the Buriat ASSR.

27. Jayak-Gegen (Jayaksen-Gegen): A line of Tibetan reincarnated lamas who resided at Gumbum Jampaling Monastery.

28. Gumbum Jampaling (Tibetan: sku 'bum byams pa gling) - the major Tibetan Buddhist monastery situated in the province of Qinghai. Founded at the end of the sixteenth century by the Third Dalai Lama at the birthplace of Je Tsongkhapa, founder of the Gelukpa School of Tibetan Buddhism. 
Shilov also held a meeting on August 1, 1921, in the locality of Chuluta of the Bodongut khoshun of the Khori aimak, involving the participation of representatives of the two warring parties. An attempt was made here to find a compromise by inviting some leaders of the balagat movement to work in the aimak and khoshun administrations. Certain advocates of theocracy were released from detention, but Lubsan-Samdan Tsydenov was not among those (Ochirzhapov, 40-43). On the orders of Shilov himself, Uvarov and Markov were arrested and taken to prison in Chita and Verkhneudinsk respectively. Later Karpovich was detained as well. Sources inform us only about Karpovich's fate: in line with a decision by the Amur guberniia court, he was subsequently shot as a counter-revolutionary (Ochirzhapov, 43).

The results of the work of the Shilov Commission were further strengthened by the work of yet another commission, appointed by the government of the Far Eastern Republic. N. Prelovsky was appointed to head this commission. The activity of the Shilov and Prelovsky commissions led to a compromise with the advocates of theocracy. Just as was the case with Semyonov and his followers, the authorities of the Far Eastern Republic had no interest in the worsening of relations with the Buddhists of Kizhinga. In September 1921, prominent figures in the balagat movement were elected as deputies to the Buriat-Mongol Region's popular assembly for the Khori aimak. In the aimak itself, at a gathering of the inhabitants of the Bodongut khoshun on September 25, 1921, a truce between the advocates of theocracy and the advocates of autonomy was achieved, and they agreed to establish peaceful relations and to begin cooperating with each other, under the aegis of the government of the Buriat-Mongol Autonomous Region (Ochirzhapov, 43-50).

\section{The Point of No Return}

In the Popular Assembly, deputies of the theocratic faction participated actively in parliamentary work, although they did not enter the regional government (the Buriat-Mongol Autonomous Administration or Burmonavtupr). Nevertheless, progress was evident, and to many people it began to seem possible that the problem of the balagat movement was gradually approaching a solution. However, in reality there was soon to be a new round of opposition that would eventually reach the stage of an armed struggle. A new conflict was provoked by baseless rumors (which began to become exaggerated in Buriat circles) regarding the BMAR government's plans to introduce 
a military tax and renew the military conscription of Buriats into the ranks of the Red Army. Representatives of the theocracy faction who were disturbed by this again brought up the question with the government of the BMAR as to whether the khoshuns of Bodongut, Tsagan and Khal'bin should leave the region and join the Baikal Region (Ochirzhapov, 50-54).

On this occasion the response of the Buriat-Mongol Autonomous Region (BMAR) government was decisive. First of all the head of that government, Matvei Amagaiev, called on the theocracy faction to become reconciled to the idea of Buriat autonomy, which in no way influenced the position of the supporters of the balagat movement. Then the BMAR government accused the theocracy faction of attempting to avoid paying taxes and meeting their obligations, principally their transport and military service obligations. These were the terms in which, in February 1922, the BMAR government presented the case to the government of the Far Eastern Republic (Ochirzhapov, 50). As soon as March of that year, on the order of K. Il'in, inspector of police, the main participants in the balagat movement were subject to arrest: these were Sandylyg Gonchikdarayev, former president of the balagat state; Naidan Sampilov, head of the Chuluta datsan that had broken off from the broader Buddhist community; Badmatsyren Boniiev, former minister of foreign affairs of the Balagat state; Badmatsyren Garmaiev, former associate of the minister of finance of the Balagat state, and others (Ochirzhapov, 50-51). The theocracy faction responded to this with armed resistance. They mustered an armed detachment of 150 men and sent it to the administration of the Bodongut khoshun, where, according to their information, those under arrest were being detained. The detachment did not succeed in liberating their associates because by that time they had been transferred to Verkhneudinsk (Ochirzhapov, 51). However, this move on the part of the theocracy faction led to irreversible consequences. The point of no return had been crossed.

\section{Defeat of the Movement}

The theocracy faction's attempt to liberate their leaders led to all the arrested supporters of Lubsan-Samdan Tsydenov, and also Tsydenov himself, being sent off into administrative exile in far-distant territories and regions of the RSFSR. The government of the BMAR issued an ultimatum to the armed detachments of the theocracy faction (Ochirzhapov, 54). 
Lubsan-Samdan Tsydenov set off on his enforced exile, and traces of him were lost. There is information available to the effect that in May 1922 he was admitted to the city hospital in Novo-Nikolaevsk, where he died of pleurisy affecting the left side of his body (Dandaron 2006, 276). In effect, the history of the Kudun theocracy ends with his death. Throughout the 1920 s the scattered remnants of the theocracy faction were annihilated by the organs of power, first those of the Far Eastern Republic and then by those of the RSFSR. The further history of the balagat movement is a history of armed struggle, repression, court trials and executions and imprisonment by the decisions of the courts of various authorities, acts of revenge, mob law, partisan war and, eventually, complete defeat of the advocates of the idea of a Kudun theocracy. The last trial of a group of supporters of the balagat movement took place in the village of Aninsk in June 1929 , as a result of which one person was sentenced to be shot and five others received prison sentences ranging from five to ten years (Ochirzhapov, 78).

\section{Conclusion}

It is hardly possible to call the Kudun theocracy a successful statebuilding project. As is clear from the sketch provided above, despite the structure developed for the state apparatus and the procedure for setting up organs of power, the theocratic government could not fully meet its obligations. Nevertheless, the sources used for the present article allow us to draw some cautious conclusions regarding the essential nature of the Kudun state project.

As is well known, modernist ideas that arose in traditional Eastern cultures were never a simple reflection of their European models, but, rather, they acquired their specific features and their unique configuration on the Procrustean bed of their own worldview. The means of appropriating political ideas were closely connected with European colonialism, which is evident when we analyze the history of the Buriat Buddhists, who always formed part of the pax mongolica and the Tibetan Buddhist world, even after becoming a constituent part of the Russian state. A detailed examination of such episodes in the history of Buddhism as the Kudun theocracy gives researchers the possibility of understanding the nature of the transformation of the theocracies of Outer Mongolia and Tibet. Influenced by a European paradigm for state formation, the Buriats became one of the first Buddhist peoples who were obliged to reconsider many of their traditional political concepts. 
The Buriat version of nationalism imitated Russian political culture, in which Orthodox Christianity was assigned the key role as a homogenizing force, and with its help society acquired a single political and religious identity. For the Buriats of Transbaikalia Buddhism served as a particular kind of principal "diacritical mark," which, during the imperial era, allowed them to separate themselves from the surrounding Russian Orthodox majority, and later, on that foundation, to create state structures and institutions that we actually observe in the example of the balagat movement. And it is in this sense that the ethno-religious identity of Buriat Buddhists emerged as an alternative to the model of Buriat nationalism that the Buriats were offered, first of all by bourgeois nationalists (some of whom actively collaborated with Semyonov's regime) and then by the Bolsheviks. In the example of the Kudun theocracy, we see how easily Buddhism became the basis for state formation, and Buriat nationalists themselves understood this extremely well, as did Semyonov's forces and also the Bolsheviks. The project of the Dauria Government headed by Neisse-Gegen and initiated by Semyonov in 1918, and the Bolsheviks' use of the figure of Bogdo-Gegen VIII in the period of transition to Socialist construction in Mongolia illustrate this fact well. Buriat nationalists, who at various times collaborated with tsarism and with Semyonov's White Guard and the Bolsheviks, experienced the strong influence of the ideas of Romantic Pan-Slavism and Pan-Germanism. In their own picture of the future, Tibetan Buddhism was a force capable of prompting the unification of the Mongol peoples. However, in their conception religion occupied a subordinate place and was conceived of as an instrument, not as a foundation for government. Their nationalism included a religious aspect, but merely as a marker of group identity, not as a basis for promoting national claims. They could be Buddhists, while remaining secular, and the model of their imagined state was also particularly secular. Their opponents, who included Lubsan-Samdan Tsydenov, advocated a purely religious state and Buddhist nation. That is exactly why the Kudun theocracy has such a complicated and dramatic history of mutual relations with the secular Buriat nationalists in particular, who the theocracy's supporters viewed as their own chief enemies and opponents.

The Kudun state-building project is also interesting in that, while outwardly striving to reproduce an ideal, archetypal model of a Buddhist state of the Maurya Empire of the time of Ashoka, it was the first attempt to construct this kind of theocracy within the framework of a constitutional republic. The electoral principle permeates the entire system of representation in the balagat state. Despite the fact that 
the figure of supreme ruler was placed above the fundamental law, the very attempt to reconcile monarchy and republic supports the thesis that the Kudun project took shape in the context of Russian political reality, although in form it was also copying examples of the Buddhist theocracies of Tibet and Mongolia. The factor that the Kudun theocracy has in common with other forms of Buddhist monarchy existing in Inner Asia is this sustained ideological opposition to the idea of armed defense of one's own statehood. The circumstances of revolution and civil war created the conditions for the violent annihilation of this state-building project and its initiators. But, at the same time, it may have saved the lives of many young people, who would otherwise have been called to serve in the ranks of various armed services.

\section{References}

Archival Sources

Archive of L.-S. Tsydenov (Manuscripts). Tibetan Holdings of the Center for Oriental Manuscripts and Xylographs of the Institute of Mongolian, Buddhist and Tibetan Studies.

Konstitutsiia gosudarstva Erkhene Balgasan Ulus [Constitution of the Erkhe Balgasan Ulus] (Manuscript text in Mongolian). Personal Archive of N. V. Tsyrempilov.

Ochirzhapov, Ts. M. Teokraticheskoe balagadskoe dvizhenie i banditizm po Khoriomu aim$a k u v$ 1917-1927 gg. (Typewritten document). [The theocratic balagad movement and banditry in Khori aimak]. Personal Archive of N. V. Tsyrempilov.

Opisanie aresta L.-S. Tsydenova [Description of L.-S. Tsydenov's arrest] (Manuscript text in Mongolian). Mongolian Holdings, Collection of the Center for Oriental Manuscripts and Xylographs of the Institute of Mongolian, Buddhist and Tibetan Studies, Inv. No. M 1, 516.

Tsydenov, L.-S. Novaya pesn', vdokhnovlennaia velikoi radost'iu po sluchaiu okonchatel'nogo vosshestviia na nerushimii almaznii tron mogushchestvennogo chakravartina, bozhestva, ustanovlennogo nebom, Tsaria Nikolaia, voskhvaliaiushchaia intronizatsiuu, rasskazyvaiushchaia vkratse takzhe i o slave Rossii, obretshei mogushchestvo dvukh stolits, nazyvaiushchaiasia "Mnogokratno vziraiushchaia na ustrashaiushchikh bengal'skikh i afrikanskikh l'vov v Zoologicheskom $s a d u$ " [New song inspired by the great joy of the eventual ascent to the indestructible diamond throne of the mighty Cakravartin, the deity established by heaven, Tsar Nicholas, praising the enthronement, narrating briefly the glory of Russia that acquired the might of two capital cities, called "Repeatedly gazing at the terrifying Bengal and African lions in the zoological garden"] (Manuscript in Tibetan). National Museum of the Republic of Buryatia. Temporary Holding, File 422.

Tsydenov, L.-S. Pis'ma i dokumenty L.-S. Tsydenova (rukopisi). [Letters and documents of L.-S. Tsydenov (manuscripts)]. Personal Archive of L.-S. Tsydenov, Center for Oriental Manuscripts and Xylographs of the Institute of Mongolian, Buddhist and Tibetan Studies, File 636.

Zhigmidon, B. Kontrrevoliutsiia pod maskoi teokratizma (Balagatchina) [Counter-revolution under the mask of theocratism (Balagatchina)] (Typewritten document). National Museum of the Republic of Buryatia. Temporary Holding, File 422. 


\section{Secondary Sources}

Bartanova, A. A. 1964. Obrazovanie Buriatskoi Avtonomnoi Sotsialisticheskoi Respubliki [Formation of the Buriat Autonomous Soviet Socialist Republic]. Ulan-Ude: Buriatskoe knizhnoe izd-vo.

Bazarov, B. V., and L. B. Zhabaeva. 2008. Buriatskie natsional'nye demokraty i obshchestvenno-politicheskaia mysl' mongol'skikh narodov $v$ pervoi treti XX veka [Buriat Nationalist Democrats and social-political thought of the Mongolian peoples of the first third of the twentieth century]. Ulan-Ude: Izd-vo Buriatskogo nauchnogo tsentra.

Chimitdorzhin, D. G. 2010. Pandito Khambo Lamy (1764-2010). Ulan-Ude: D. G. Chimidorzhin.

Dameshek, L. M. 1986. Vnutrenniaia politika tsarizma i narody Sibiri. XIX-nachalo XX veka [Domestic policies of tsarism and the peoples of Siberia: The nineteenth to early twentieth century]. Irkutsk: Izdatel'stvo Irkutskogo universiteta.

Dandaron, B. D. 2006. Izbrannye stat'i. Chernaia tetrad'. Materialy k biografii. "Istoriia Kukunora” Sumpy Kenpo. Edited by V. M. Montlevich [Selected works: The black notebook; Materials toward a biography; “The History of Kukunor,” by Sumpa Kenpo]. Moscow: Evraziia.

Gerasimova, K. M. 1957. Lamaizm i natsional'no-kolonial'naia politika tsarizma $v$ Zabaikal'e $v$ XIX i nachale XX vekov [Lamaism and national-colonial policy of tsarism the nineteenth to early twentieth century Transbaikalia]. Ulan-Ude.

Istoriia Buriatii $v 3$ t. 2011. [The history of Buryatia in 3 volumes]. Vol. 3, The 2oth-21st Centuries. Ulan-Ude: The Buriat National Center, Russian Academy of Sciences, Siberian Division (RAN SO).

Krol', Moisei. 2004. “Gody ssylki. V gostiakh u Sviatogo Lamy” [Years of exile: Visiting a holy lama]. Vostochnaia kollektsiia [Eastern collection] 4 (19): 74-80.

Natsagdorzh, Ts. B. 2015. "Buddiiskii faktor v obshchemongol'skoi identichnosti rossiiskikh buriat v XVIII v." [The Buddhist factor in Mongolian identities of the Russian Buriats]. In K 25O-letiiu instituta Pandito Khambo-lam v Rossii: Sbornik nauchnykh statei [On the occasion of the 250th anniversary of the institution of the PanditoKhambo lama in Russia: Collection of academic articles], edited by V. L. Uspensky, 18-39. St. Petersburg: Peterburgskoe vostokovedenie.

Podgorbunskii, I. 1901. Buddizm, ego istoriia i osnovnye polozheniia ego ucheniia [Buddhism, its history and fundamental elements of its teaching]. Irkutsk.

Rupen, Robert A. 1964. Mongols of the 2oth Century. Vol. 1. Bloomington: Indiana University Press.

Tsyrempilov, N. V. 2007. "Lubsan Samdan Tsydenov i ego ideia buddiiskoi teokratii v Zabaikal'e" [Lubsan-Samdan Tsydenov and his idea of Buddhist theocracy in Transbaikalia]. Vostok (Oriens), no. 6 (November - December): 45-52.

Tsyrempilov, N. V. 2015. Buddizm i imperiia: Buriatskaia buddiiskaia obshchina i Rossiiskoe gosudarstvo XVIII-nach. XX v. [Buddhism and empire: The Buriat Buddhist community and the Russian state in the 18th century-early 2oth century]. UlanUde: Buriaad Mongol Nom. 